\title{
Dehydration of potato slices following brief dipping in osmotic solutions: effect of conditions and understanding the mechanism of water loss
}

Article

Accepted Version

Mokhtar, W. M. F. W., Ghawi, S. K. and Niranjan, K. (2019) Dehydration of potato slices following brief dipping in osmotic solutions: effect of conditions and understanding the mechanism of water loss. Drying Technology, 37 (7). pp. 885895. ISSN 1532-2300 doi:

https://doi.org/10.1080/07373937.2018.1473418 Available at https://centaur.reading.ac.uk/76981/

It is advisable to refer to the publisher's version if you intend to cite from the work. See Guidance on citing.

To link to this article DOI: http://dx.doi.org/10.1080/07373937.2018.1473418

Publisher: Taylor and Francis

All outputs in CentAUR are protected by Intellectual Property Rights law, including copyright law. Copyright and IPR is retained by the creators or other copyright holders. Terms and conditions for use of this material are defined in the End User Agreement. 


\section{www.reading.ac.uk/centaur}

\section{CentAUR}

Central Archive at the University of Reading

Reading's research outputs online 


\section{Manuscript LDRT-2017-0468 (Version R1)}

Dehydration of Potato Slices Following Brief Dipping In Osmotic Solutions: Effect of Conditions and Understanding the Mechanism of Water Loss

Wan Mohd Fadli Wan Mokhtara,b, Sameer Khalil Ghawi ${ }^{\mathrm{a}}$, Keshavan Niranjan ${ }^{\mathrm{a}, *}$

aDepartment of Food and Nutritional Sciences, University of Reading, Whiteknights P.O.

Box 226, Reading RG6 6AP, United Kingdom.

${ }^{\mathrm{b}}$ School of Food Industry, Faculty of Bioresources and Food Industry, Universiti Sultan

Zainal Abidin, Terengganu, Malaysia.

*Address correspondence to Prof. Keshavan Niranjan, Department of Food and Nutritional Sciences, University of Reading, Whiteknights P.O. Box 226, Reading RG6 6AP, United Kingdom.

Email: afsniran@ reading.ac.uk 


\begin{abstract}
A novel variant of osmotic dehydration, named here as post-dipping dehydration where a material is dipped in a salt or sugar solution for a very short time followed by simple exposure to ambient conditions was explored with the aim of lowering water content of potato slices but at the same time not gain a high level of sugar/salt. The rate of water loss, which was rapid initially, was found to approach equilibrium. This paper also explored whether the water loss process could subsequently be kick started once again, by employing a multi-stage process, where each stage consisted of osmotic solution dipping followed by ambient holding of the potato slices that had reached equilibrium in the earlier stage. Water loss values comparable to conventional osmotic dehydration could be achieved thus, but with significantly lower overall solid gain (less than 50\%) - which can potentially yield a significantly healthy product option.
\end{abstract}

KEYWORDS: Osmotic dehydration, post dipping dehydration, multi-stage dehydration, solid gain, process efficiency index. 


\section{Introduction}

Hot air drying is an ancient and extensively employed process to reduce moisture content and increase the shelf life and stability of food products. The process involves simultaneous heat and mass transfer ${ }^{[1]}$. A major drawback of hot air drying is quality deterioration of the products due to exposures to a high temperature for extended periods of time. Another drawback is that this technique requires the expenditure of high energy ${ }^{[2]}$. Therefore, a number of alternative energy efficient dehydration techniques have been developed resulting in better quality food products.

Osmotic dehydration eliminates water from materials without expending latent heat. It essentially involves immersion of materials such as fresh fruits or vegetables in a concentrated solution. Due to osmotic driving force generated between the hypertonic solution and tissue, three mass transfer phenomena occur i.e. i) water removal from tissue, ii) leaching out of other components from the tissue, and iii) influx of solute from the concentrated solution into the tissue ${ }^{[3,4]}$. This method of dehydration has yielded promising

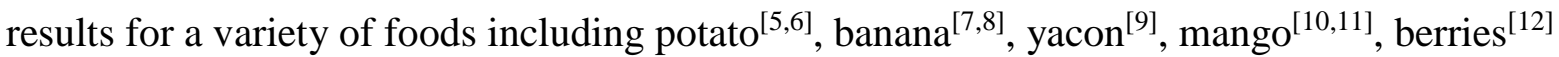
and pineapple ${ }^{[13,14]}$. In addition to low energy consumption, this method also preserves some key sensory characteristics of the fruit and vegetable. Due to its simple and inexpensive operation, it has also been applied as a pre-processing step prior to operations such as conventional drying ${ }^{[15,16,17]}$, freezing ${ }^{[18]}$ and frying ${ }^{[19]}$.

Despite the advantages of osmotic dehydration, it also suffers several limitations such as floating of fruit in solution, osmotic solution managements and the main ones being high solute uptake due to diffusion of solute towards tissue cell ${ }^{[20]}$, which can potentially pose major health issues and the leaching out of water and other nutritious components from the 
tissue, which not only affects the product but also dilutes the osmotic solution thereby adversely influencing the osmotic driving force ${ }^{[21]} \cdot{ }^{[22,23,24,25]}$ were demonstrated a thin layer of osmotic solution by on the fruit surface by using spray mode in order to overcome this problem. However, a spray mode has potential in non-uniform distribution of solution on the entire fruit surface. Thus, there is an acute need to find ways of enabling the water from the tissue to diffuse into the osmotic solution, but at the same time, not allow high levels of the osmotic solute to diffuse into the tissue.

This study aims to achieve this objective by employing brief dipping of fresh material slices, in order to allow the osmotic medium to occlude to the surface of the slices, then hold the slice under ambient conditions, which allows the osmotic driving force generated between the surface of the slice and interior to expel water, which subsequently drips out or evaporates from the surface. Water loss can therefore, be achieved for as long as the osmotic driving force prevails between the surface and the interior of the slice, without expending any energy or even gaining significant levels of solid. This novel method of water loss has not been studied so far, and the specific objectives of the study are to: (1) investigate the effects of the concentration of the dip solution, dipping time and post-dipping holding time on the water loss and solid gain patterns; (2) compare the extents of water loss and solid gain with conventional osmotic dehydration; (3) understand the mechanism of water loss; and (4) explore whether a multi-stage process consisting of repeated dipping in osmotic solution followed by holding under ambient conditions, can be used as an alternative to conventional osmotic dehydration. 


\section{Materials and methods}

\section{Materials}

Fresh potatoes (Solanum tuberosum L.) of Maris Piper variety were purchased from local store and kept in a refrigerator at $4^{\circ} \mathrm{C}$. Commercial sucrose and sodium chloride $(\mathrm{NaCl})$ were purchased from local markets.

\section{Preparation of Potato Slices and Osmotic Solutions}

Potatoes were removed from the refrigerator and left out for at least 12 hours to reach the ambient temperature before processing. Potatoes weighing around $170-230 \mathrm{~g}$ were selected for experiments. The potatoes were washed, peeled and horizontally sliced (perpendicular to the longer side) into $1.5 \mathrm{~mm}$ thick slices using an adjustable hand slicer (Mandoline slicer, Lakeland, UK). Subsequently, the potato slices were cut into disk shape (50 mm diameter) using a circular mould to ensure uniformly sized experimental slices. Potato slices were rinsed in running water (for $30 \mathrm{~s}$ ) immediately after slicing in order to remove the excess starch adhering on the surface, and finally the surface water was eliminated using tissue paper and weighted. The osmotic solutions were obtained by dissolving commercial sucrose or $\mathrm{NaCl}$ in distilled water.

\section{Single Stage Dip Dehydration and Osmotic Dehydration Treatments}

For each experiment, $10 \mathrm{~g}$ of identical potato slices were dipped in osmotic solution (sucrose solution: 30,40 and $50 \% \mathrm{w} / \mathrm{v}$ or $\mathrm{NaCl}: 5,10$ and $15 \% \mathrm{w} / \mathrm{v}$ ) for short time at 0.5 or $1.5 \mathrm{~min}$. These times were sufficient to ensure that the entire potato slices surfaces were occluded with osmotic solution and at the same time, to study the effect of dipping time on the mass transfer. The dip solution concentrations used were selected so as to result in water loss rates which were significant enough to validate our hypothesis. To be very specific, the water 
activity $\mathrm{a}_{\mathrm{w}}$ of the dip solutions were: $0.983 \pm 0.005,0.956 \pm 0.009$ and $0.932 \pm 0.004$ for $30 \%, 40 \%$ and $50 \%$ sucrose solutions, and $0.976 \pm 0.002,0.924 \pm 0.003$ and $0.891 \pm 0.010$ for $5 \%, 10 \%$ and $15 \% \mathrm{NaCl}$ solutions, respectively. Preliminary studies showed that the postdipping water loss was very low when the dip solution concentration was less than $30 \%$ in the case of sucrose and 5\% in the case of $\mathrm{NaCl}$. Preliminary experiments also showed that there was no added benefit of raising the solution concentration above $50 \%$ in case of sucrose and $15 \%$ in case of $\mathrm{NaCl}$, because the subsequent water loss kinetics were not significantly different from the highest concentrations used in this work. The mass ratio of the potato slices to the osmotic solution was kept at 1:30 and the dipping temperature was maintained between $20-22^{\circ} \mathrm{C}$.

After dipped for the stipulated time, the potato slices were taken out and then placed on a stainless steel mesh under ambient conditions (temperature: $20-22^{\circ} \mathrm{C}$ and relative humidity: $29-33 \%$ ) for dehydration to occur. At given total times, which is a combination of dipping and holding time at 5,10,20,30, 40 and $60 \mathrm{~min}$, samples were very gently blotted with a tissue paper to eliminate the adhering osmotic solution on the potato surface and analysed.

Osmotic dehydration of similar potato slices was also carried out in sucrose $50 \%$ and $\mathrm{NaCl}$ $10 \%$ solutions in order to compare the water loss and solid gain values with dip dehydration process. In this case, the potato slices were immersed in the osmotic solution, and samples were taken out after 5, 10, 20, 40, 60, 80, 120, 160, 200 and 240 minutes (in sucrose) and 5, $10,20,30,40,50,60,70$ and 80 minutes (in $\mathrm{NaCl}$ ) immersion, gently blotted with a tissue paper to remove the excess osmotic solution and analysed. 


\section{Multi-stage Dip Dehydration}

Multi-stage dipping and holding was carried out in two ways. In treatment A, two osmotic solutions which are sucrose $50 \%$ and $\mathrm{NaCl} 10 \%$ were chosen. Potato slices were dipped for $0.5 \mathrm{~min}$ in the osmotic solution and held for dehydration to occur under ambient conditions for approximately 40 mins (in sucrose case) and 10 mins (in $\mathrm{NaCl}$ case) of total time, when the osmotic driving force between the surface of the slice and the interior was too low for dehydration to occur as observed on the single stage dip dehydration case. The slices were then again dipped in the same osmotic solution at the same dipping time and held under ambient conditions for another 40 mins (in sucrose case) and 10 mins (in $\mathrm{NaCl}$ case) of total time, and the process of dipping and holding were repeated 6 times (in sucrose case) and 8 times (in $\mathrm{NaCl}$ case) in order to achieve equilibrium of water loss rate. In another multi-stage treatment B, subsequent dipping involved brief immersion in progressive concentrated solutions. Table 1 summarises the osmotic solution concentrations and total times (combination of dipping and holding times) employed in this study. At every 40 min (in sucrose case) and 10 min (in $\mathrm{NaCl}$ case) of total time, replicate samples were blotted with tissue and analysed.

\section{Water Activity and Moisture Content Determination}

Water activity of osmotic solution and potato slices were analysed using HygroLab 3 (Rotronic, Sussex, U.K.). Meanwhile, for moisture content analyses, samples were weighed and dried at $105^{\circ} \mathrm{C}$ in a convection oven (Weiss-Gallenkamp, Loughborough, U.K.) for approximately 24 hours until a constant weight was achieve ${ }^{[26]}$. The moisture content wet basis and dry basis were determined from:

$$
M C_{\text {wet basis }}(\%)=\frac{M_{\text {wet }}-M_{\text {dry }}}{M_{\text {wet }}} \times 100
$$




$$
M C_{d r y \text { basis }}(\%)=\frac{M_{w e t}-M_{d r y}}{M_{d r y}} \times 100
$$

where $M_{w e t}$ is a mass of the wet sample (g) and $M_{d r y}$ is a mass of the solid content of the sample after drying to constant weight in an oven at $105^{\circ} \mathrm{C}(\mathrm{g})$.

\section{Water Loss (WL) and Solute Gain (SG) Determination}

The WL and SG were calculated from the following equations ${ }^{[27]}$ :

$$
\begin{aligned}
& W L\left(\frac{g}{100 g} \text { of fresh sample }\right)=\frac{\left(M_{0} x_{0}-M_{t} x_{t}\right)}{M_{0}} \times 100 \\
& S G\left(\frac{g}{100 g} \text { of fresh sample }\right)=\frac{\left(M_{t} s_{t}-M_{0} s_{0}\right)}{M_{0}} \times 100
\end{aligned}
$$

where $M_{0}$ and $M_{t}$ are the sample masses initially and at time, $t$ respectively; $x_{0}$ and $x_{t}$ are the moisture fractions (g/g wet basis) initially and at time, $t$; and $s_{0}$ and $s_{t}$ are the dry solid fractions $(\mathrm{g} / \mathrm{g})$ initially and at time, $t$. The above equations assume that there is no solute transferred from the sample to the solution.

\section{Determination of Remaining Total Solute Content of Osmotic Solution on Potato Slices}

The remaining total sucrose or $\mathrm{NaCl}$ that occluded and diffused into the potatoes slices after dipped in osmotic solution over total time was determined by other experimental works. After potato slices were taken out from dipping solution and hold at the given total time of dip dehydration treatment, samples were dried in an oven until constant weight in order to determine the total sucrose or $\mathrm{NaCl}$ content on the potato slices. The total sucrose or $\mathrm{NaCl}$ content was calculated from the weight of difference between dipped and fresh samples and expressed as $\mathrm{g} / 100 \mathrm{~g}$ of the fresh sample. 


\section{Process Modelling}

Three well-known empirical models (Table 2) were used to fit the water loss kinetics ${ }^{\text {[2][28][29] }}$ of dip dehydration and the fitting was performed using cftool in MATLAB (R2016b) software (The MathWorks, Inc., UK) in order to determine the model constants.

The statistical parameters such as coefficient of determination $\left(\mathrm{R}^{2}\right)$, root mean square error (RMSE), average relative error (E) were used to compare the goodness of fit [30]. The best model must possess the highest $\mathrm{R}^{2}$, the least of RMSE and $E$, defined as follows [31]:

$$
\begin{gathered}
R^{2}=1-\left[\frac{\sum_{i=1}^{N}\left(W L_{i}-W L_{p r e, i}\right) \cdot\left(\sum_{i=1}^{N}\left(W L_{i}-W L_{\text {exp }, i}\right)\right.}{\sqrt{\left[\sum_{i=1}^{N}\left(W L_{i}-W L_{\text {pre }, i}\right)^{2}\right] \cdot\left[\sum_{i=1}^{N}\left(W L_{i}-W L_{\text {exp }, i}\right)^{2}\right]}}\right] \\
R M S E=\sqrt{\left[\frac{\left.\sum_{i=1}^{N}\left(W L_{\text {pre }, i}-W L_{\text {exp }, i}\right)^{2}\right]}{N}\right]} \\
E=\frac{1}{N} \sum_{i=1}^{N}\left|\frac{\text { Experimental value }- \text { Predicted value }}{\text { Experimental value }}\right|
\end{gathered}
$$

\section{Statistical Analysis}

Two batches of each experiment were performed and potato samples were collected from each batch in triplicate for analysed. All experimental data reported in figures and tables are the mean and standard deviation values that calculated by using Microsoft Office Excel 2013 and were evaluated using Minitab 17 Statistical Software. A t-test was used to determine the significant difference involving two samples (each sample with replication data), while a oneway analysis of variance (ANOVA) with Tukey's test was used to determine the significant difference involving more than two samples (each sample with replication data) at $95 \%$ confidence level. 


\section{Results and discussion}

\section{Effect of Process Parameters and Nature of Osmotic Solutions on Single Stage of Dipping}

\section{Dehydration Water Loss}

Fig. 1 depicts WL as a function of total time (i.e. expressed as a combination of dipping and holding times). The potato samples were dipped in sucrose (30 to $50 \%$ ) and $\mathrm{NaCl}$ (5 to $15 \%$ ) solutions for 0.5 and 1.5 min, withdrawn, and left to dehydrate. Fig. 1 clearly demonstrates high initial water loss (WL) which becomes progressively slower in all cases. This patterns of water loss is similar to conventional osmotic dehydration ${ }^{[8][32][33]}$. Based on statistical analysis, the value of WL significantly increased with total time for $10 \min (p<0.05)$ in the case of $\mathrm{NaCl}$ and for $40 \mathrm{~min}$ in the case of sucrose solutions, after which the values of WL increased at a much slower rate. It can be postulated that the initial increase in WL is more pronounced due to the existence of a greater osmotic driving force between the fresh sample and concentrated solution which adheres to the surface of the sample.

Subsequently, water diffusion rate from interior to the surface becomes slower as the osmotic agent adhering to the potato surface, becomes diluted by the water that has already diffused from the interior. Fig. 1 shows that there is no significant $(p>0.05)$ effect of dipping time on WL in all cases. This is because the dipping times are relatively short and insufficient either for the sugar/salt to penetrate, or for the water to leave the tissue. Hence, the dipping time of 0.5 min was chosen for performing further experiments. Fig. 1 also shows that the WL curve for sucrose and $\mathrm{NaCl}$ solutions follow similar trend, and as expected, the WL values are higher when the samples are dipped in solutions having greater concentrations.

Fig. 1 also shows that WL increased with the concentration of the dip solution $(p<0.05)$ for both sucrose and $\mathrm{NaCl}$ solution. For example, the maximum WL value for samples dipped in 
$50 \%$ sucrose at $0.5 \mathrm{~min}$ is $31.09 \pm 0.74 \mathrm{~g} / 100 \mathrm{~g}$ whereas it is only $22.86 \pm 0.51 \mathrm{~g} / 100 \mathrm{~g}$ for samples dipped in $30 \%$ sucrose solution. Likewise, in the case of $\mathrm{NaCl}$ solution, the maximum WL value for $10 \%$ solution is $18.76 \pm 0.76 \mathrm{~g} / 100 \mathrm{~g}$ whereas for the $5 \%$ solution, it is $16.56 \pm 0.42 \mathrm{~g} / 100 \mathrm{~g}$. It is also interesting to note that the increase in WL with dip solution concentration tapers off in the case of $\mathrm{NaCl}$ because there is no significant difference between the WL values between 10 and 15\% solutions. These observations on the effects of dip solution concentrations are similar to those in conventional osmotic dehydration. For example, ${ }^{[9,10,34,35]}$ observed that WL increases with osmotic solution concentrations. ${ }^{[36,37]}$ have also reported in the case of apricot and potato that WL does not change dramatically at high osmotic solution concentration, which these authors attribute to "case hardening" caused by high concentrations of infuse salt. It is necessary to note that even though the trends in variation of WL with solution concentrations are similar to osmotic dehydration, the solute concentration in the tissue are significantly lower (Table 5).

It is also interesting to compare the above WL values obtained after dipping the potato sample in various solutions, with the values for identical samples which are not subjected to any dipping process (control), and samples subjected to conventional osmotic dehydration treatment. For untreated samples, the dewatering is due to natural evaporation. It is obvious that the dipped slices gave significant higher water loss $(p<0.05)$ according to Fig. 1 . The results show that the non-dipped control sample attained a WL value of only $10.75 \pm 0.45$ $\mathrm{g} / 100 \mathrm{~g}$ after $60 \mathrm{~min}$ whereas the samples dipped in sucrose attained three times this value. In the case of osmo-dehydrated samples, the WL value is four times higher than control sample at $42.86 \pm 1.61 \mathrm{~g} / 100 \mathrm{~g}$ of fresh sample. 
In order to demonstrate the practical benefits of post-dip dehydration, it is illustrative to compare the actual moisture content of the various samples (Table 3). The average initial moisture content of samples was $475 \pm 47 \%$, which, after 60 minutes reduced to $225.65 \pm$ $15.10 \%$ in the case of post-sugar-dip water loss, $175.73 \pm 13.47 \%$ in the case of conventional osmotic dehydration in the same solution, and $392.20 \pm 6.54 \%$ in the case of ambient air drying. It is obvious that post-dip moisture loss is significantly closer to conventional osmotic dehydration than to air drying. Of course, the moisture loss in the case of conventional osmotic dehydration is higher, which can simply be attributed to the higher sugar/salt concentrations. It is also for this very reason that osmotically dehydrated samples lose water continuously while the dipped samples attain constant moisture content values. Table 3 also lists the water activity for all cases. According to ${ }^{[38]}$, water activity is good indicator to determine the shelf life of food products. Table 3 shows that the water activity decreased over time for dip-dehydrated samples due to decrease water loss as discussed before. Generally, further process such as drying and frying is operate to minimize water activity of osmodehydrated samples at desired value to prevent any microbial activity.

\section{Mechanism of Dip Dehydration Water Loss}

When the sample is withdrawn from the dip solution, a layer of the dip solution gets occluded to the surface, and a concentration driving force results between the bulk and the surface of the potato sample, which moves the water from the interior towards the surface. At the surface, the water can evaporate or the solution can drain out of the sample. The concentration of the solute at the surface does not reach a steady state and therefore the commonly assumed quasi-steady state surface concentration does not apply. The osmotic gradient between the tissue cells and the surface is also unsteady and therefore the rate of water loss from the tissue remains unsteady. Fig. 2 illustrates the rate of water loss in the case 
of samples dipped in $50 \%$ sucrose and $10 \% \mathrm{NaCl}$ solutions, and compares these rates with the values observed in non-dipped samples. It may be noted that the rates in Fig. 2 essentially represents the local gradients of WL versus time data shown in Fig. 1. It is evident from Fig. 2 that the dehydration rate generally decreases with time in all cases. For the untreated sample, the initial dehydration rate is $0.37 \mathrm{~g} \mathrm{H}_{2} \mathrm{O}(100 \mathrm{~g} \text { of fresh sample })^{-1} \mathrm{~min}^{-1}$ and decreases steadily to less than $0.13 \mathrm{~g} \mathrm{H}_{2} \mathrm{O}(100 \mathrm{~g} \text { of fresh sample })^{-1} \mathrm{~min}^{-1}$ in later stages. Water loss from the surface sample is essentially by evaporation, and since all samples are dehydrating under the same ambient conditions the rates of evaporation would be expected to be the same. It is clear from Fig. 2 that after $10 \mathrm{~min}$, the control sample is dehydrating at the rate of $0.21 \mathrm{~g} \mathrm{H}_{2} \mathrm{O}$ (100g of fresh sample $)^{-1} \mathrm{~min}^{-1}$, which may be assumed to represent the rate of evaporation. At the same time, the salt and sucrose dipped samples are losing water at a much higher rate. The difference between the two rates can be assumed to indicate the rate at which the water drains from the sample in the liquid state taking with it some solute.

\section{Kinetics in Water Loss}

The water loss data shown in Fig. 1 can be fitted to three selected empirical models, which are commonly used in dehydration literature: Azuara ${ }^{[28]}$ Page $^{[2]}$ and Peleg ${ }^{[29]}$. The values of the model parameters and relevant statistical data are given in Table 4 , which shows that $\mathrm{R}^{2}$ for all models are greater than 0.91 with low RMSE values $(<0.024)$. However, it was found that Peleg model satisfactorily described the dehydration behaviours with the highest $\mathrm{R}^{2}$ (>0.98) and lowest RMSE $(<0.018)$.

\section{Solute Gain (SG) Behaviour}

The solute gain estimated from Eq. 4 is given in Table 5. It may be noted that the solute gain is expressed in $\mathrm{g}$ solid per $100 \mathrm{~g}$ fresh sample. Table 5 shows that there are significant 
increases in solute gain values with total time for both dip dehydration and conventional osmotic dehydration in sucrose and $\mathrm{NaCl}$ solutions, but conventional osmotic dehydration always exhibits higher solute gain value than dip dehydration samples. For example, solute gain in the case of conventional osmotic dehydration were $7.06 \pm 0.44 \mathrm{~g} / 100 \mathrm{~g}$ for sucrose $50 \%$ and $5.00 \pm 0.48 \mathrm{~g} / 100 \mathrm{~g}$ for $\mathrm{NaCl} 10 \%$ after $60 \mathrm{~min}$ of osmotic dehydration. These values are nearly twice the value of the solid gain in the case of dip dehydration. Thus, by employing dip dehydration, we can achieve osmotic water loss with considerably reduced solid gain, which is potentially health beneficial.

Table 6 shows the values of process efficiency index (WL/SG) for both dip and osmotic dehydration of potato slices. This ratio of water loss/solid gain is an important indicator to evaluate the efficiency of osmotic dehydration technique ${ }^{[39]}$. It was observed, in general, the dipped samples presented higher value of efficiency index as compared with osmodehydrated samples. The advantage of dip dehydration treatment which lowers solid gain substantially, is the main factor contributing to the higher WL/SG values. Thus, these results indicate the superiority of dip dehydration over the osmotic dehydration treatment with respect to the lower solid gain.

Fig. 3 shows the variation in remaining total sucrose and $\mathrm{NaCl}$, which amount of solute gain and occluded on slices, expressed as the $\mathrm{g}$ of solute per $100 \mathrm{~g}$ of fresh sample, as a function of time. It is clear that the mass of solute in the potato decreases for sucrose (for the first 20 minutes) as well as $\mathrm{NaCl}$ (for the first 10 minutes) and then remains constant. The loss of solute in the initial stage is due to the solution draining from the surface. We can postulate that the water diffusing towards the surface under the osmotic gradient, dissolves the solute present near the surface, and leaches it out with the draining solution. It clearly seen from 
Fig. 3 that solute content decreased from $13.31 \mathrm{~g} / 100 \mathrm{~g}$ to $7.39 \mathrm{~g} / 100 \mathrm{~g}$ of fresh sample after 20 minutes in the case of sucrose, and from $4.38 \mathrm{~g} / 100 \mathrm{~g}$ to $2.58 \mathrm{~g} / 100 \mathrm{~g}$ in the case of $\mathrm{NaCl}$ after 10 minutes. This reduction in solute content also lowers the osmotic gradient, which in turn lowers the rate of water loss; this is clearly seen in Fig. 2. Thus the dewatering process due to osmotic dehydration becomes less effective over the period of time and ceases to occur; any water loss from surface occurring thereafter is mainly due to natural evaporation.

\section{Multi-stage Dip Dehydration}

As discussed in the previous section, the WL after the first dip in osmotic solution becomes constant after $40 \mathrm{~min}$ in the case of sucrose and $10 \mathrm{~min}$ in the case of $\mathrm{NaCl}$, due to decreases in the osmotic driving force. It was therefore thought desirable to find out whether the dehydration process could, once again, be re-started by dipping the partially dehydrated product, once again, in the osmotic solution. It is true that we are re-exposing the product to more water, but, given the short dipping time, the amount of water and salt taken up thus, will be very low. If dehydration could be successfully re-started, it was also thought desirable to explore whether water loss comparable to conventional osmotic dehydration could be achieved by a series of repeated dipping and holding processes, in other words, multi-stage dipping and dehydration. As mentioned earlier, two approaches were considered: repeated dipping in the same concentrated solution (treatment A) and dipping in progressively concentrated solution (treatment B).

Fig. 4 shows the transient WL values for multi-stage dipping and compares the data with the water loss observed in the case of conventional osmotic dehydration in the same solution. It is clear that the water loss patterns for the multi-stage process is similar to conventional osmotic dehydration, i.e. the rate WL values increase rapidly soon after dipping, but slow down in the 
later stages. It is clear from Fig. 4 that initially, the water loss values for dip dehydration is lower than conventional osmotic dehydration in the same dip solution, which is naturally expected; this is indeed a key disadvantage of the process in relation to conventional osmotic dehydration. The water loss for treatment B appears to be lower than treatment A, but this is simply because the first dip solution had a lower concentration. In the case of sucrose solution, it is clearly seen that the value of WL does not significantly change $(p>0.05)$ for all treatments after $240 \mathrm{~min}$. Although the potato slices underwent dipping in progressively higher concentrated sucrose solution up to $60 \%$ (treatment B), the WL values did not continually rise. This is due to the decrease in chemical potential of water between the tissue and solution over the process time, and the high viscosity of concentrated sucrose solution that adheres to the potato surfaces. ${ }^{[40]}$ also mentioned that the increasing sucrose concentration leads to a high viscosity of solution which creates external resistance to the water transfer rate.

It is interesting to note that even though the water loss values achieved in dip dehydration is comparable to osmotic dehydration, the solute gain (SG) is significantly lower and the process efficiency index (WL/SG) values for dip dehydration is significantly higher (Table 7).

In the case of $\mathrm{NaCl}$, the most effective method was found to be treatment $\mathrm{B}$ which achieved a maximum value of WL of $37 \mathrm{~g} / 100 \mathrm{~g}$ of fresh sample after $80 \mathrm{~min}$, whereas the WL value for treatment A and conventional OD was around $30 \mathrm{~g} / 100 \mathrm{~g}$ of fresh sample. However, it may be noted that there is no significant different in SG values between treatment B and conventional OD after $50 \mathrm{~min}$, thus resulting in treatment B giving lower WL/SG value than treatment A, but still higher than conventional OD as shown in Table 7. Furthermore, the 
lower molecular weight of $\mathrm{NaCl}(58.4 \mathrm{~g} / \mathrm{mol})$ than sucrose $(342 \mathrm{~g} / \mathrm{mol})$ enables the solute to diffuse more easily into the tissue ${ }^{[4]}$.

\section{Conclusion}

In this study, dehydration of potato slices was explored after dipping the slices briefly in concentrated sugar (30-50\%) and salt solutions (5-15\%), and leaving the slices to lose water under ambient conditions. The absorption of sugar and salt resulted in the movement of water towards the surface of the slices under osmotic gradients, which was subsequently lost from the slices by a combination of evaporation and draining. Initially, the loss of water by draining was more significant, but later on evaporation tended to dominate. The moisture content of the slices could be reduced thus from $475 \pm 47 \%$ to $225.65 \pm 15.10 \%$ in an hour, without any significant expenditure of energy and the water loss was three times higher when compared to natural air drying. It was also found that dipped potato slices gained much lower amount of sugar/salt, which could be half or even lower than the value gained during osmotic dehydration in the same solution, thus yielding higher effectiveness index (WL/SG). This technique was further extended by investigating repeated dipping in the same concentration solution (treatment A) or by dipping in progressively concentrated solutions (treatment B). It was found that the water loss in multi-stage dip dehydration was comparable to osmotic dehydration but with significantly lower solid gain. The process efficiency index (WL/SG) was also higher for multi-stage dip dehydration. Thus, dip dehydration can be used instead of osmotic dehydration to achieve the same levels of water loss but with substantially lower solid gain. 


\section{Acknowledgements}

The authors like to thank the Ministry of Higher Education, Malaysia for supporting doctoral grant, and to the Universiti Sultan Zainal Abidin, Malaysia for supporting one of the authors (Wan Mohd Fadli Wan Mokhtar) to study at the University of Reading, UK.

\section{References}

[1] Eroglu, E.; Yildiz, H. Recent developments in osmotic dehydration. Academic Food Journal 2010, 8 (6), 24-28.

[2] Ochoa-Martinez, C.I.; Ramaswamy, H.S.; Ayala-Aponte, A.A. A comparison of some mathematical models used for the prediction of mass transfer kinetics in osmotic dehydration of fruits. Drying Technology 2007, 25, 1613-1620.

[3] Chandra, S.; Kumari, D. Recent development in osmotic dehydration of fruit and vegetables: A review. Critical Reviews in Food Science and Nutrition 2015, 55, 552561.

[4] Akbarian, M.; Ghasemkhani, N.; Moayedi, F. Osmotic dehydration of fruits in food industrial : A review. International Journal of Biosciences 2014, 4 (1), 42-57.

[5] Eren, I.; Kaymak-Ertekin, F. Optimization of osmotic dehydration of potato using response surface methodology. Journal of Food Engineering 2007, 79, 344-352.

[6] Tortoe, C.; Orchard, J.; Beezer, A. Comparative behaviour of cellulosic and starchy plant materials during osmotic dehydration. Journal of the Science of Food and Agriculture 2007, 87 (7), 1284-1291.

[7] Mercali, G.D.; Ferreira Marczak, L.D.; Tessaro, I.C.; Zapata Noreña, C.P. Evaluation of water, sucrose and $\mathrm{NaCl}$ effective diffusivities during osmotic dehydration of banana (Musa sapientum, shum.). LWT - Food Science and Technology 2011, 44, 8291. 
[8] Tortoe, C.; Orchard, J.; Beezer, A. Osmotic dehydration kinetics of apple, banana and potato. International Journal of Food Science and Technology 2007, 42, 312-318.

[9] Brochier, B.; Marczak, L.D.F.; Noreña, C.P.Z. Osmotic dehydration of yacon using glycerol and sorbitol as solutes: water effective diffusitivity evaluation. Food Bioprocess Technology 2015, 8 (3), 623-636.

[10] Nagai, L.Y.; Santos, A.B.; Faria, F.A.; Boscolo, M.; Mauro, M.A. Osmotic dehydration of mango with ascorbic acid impregnation: Influence of process variables. Journal of Food Processing and Preservation 2015, 39, 384-393.

[11] Madamba, P.S.; Lopez, R.I. Optimization of the osmotic dehydration of mango (Mangifera indica L.) slices. Drying Technology 2002, 20 (6), 1227-1242.

[12] Yu, Y.; Jin, T.Z; Fan, X.; Xu, Y. Osmotic dehydration of blueberries pretreated with pulsed electric fields : Effects on dehydration kinetics , and microbiological and nutritional qualities. Drying Technology 2017, 35 (13), 1543-1551.

[13] Filho, R.S.F.; Gusmão, R.P.; Silva, W.P.; Gomes, J.P.; Filho, E.V.C.; El-Aouar, Â.A. Osmotic dehydration of pineapple stems in hypertonic sucrose solutions. Agricultural Sciences 2015, 6, 916-924.

[14] Corrêa, J.L.G.; Dev, S.R.S.; Gariepy, Y.; Raghavan, G.S.V. Drying of pineapple by microwave-vacuum with osmotic pretreatment. Drying Technology 2011, 29, 15561561.

[15] Prosapio, V.; Norton, I. Influence of osmotic dehydration pre-treatment on oven drying and freeze drying performance. LWT - Food Science and Technology 2017, 80, 401408.

[16] Lyu, J.; Yi, J.; Bi, J. ; Chen, Q.; Zhou, L.; Liu, X. Effect of sucrose concentration of osmotic dehydration pretreatment on drying characteristics and texture of peach chips dried by infrared drying coupled with explosion puffing drying. Drying Technology 
2017, 35 (15), 1887-1896.

[17] Fernandes, F.A.N.; Rodrigues, S. Application of ultrasound and ultrasound-assisted osmotic dehydration in drying of fruits. Drying Technology 2008, 26, 1509-1516.

[18] Li, J.; Chotiko, A.; Kyereh, E.; Zhang, J.I.E.; Liu, C.; Vandeker, V.; Ortega, R.; Bankston, D.; Sathivel, S. Development of a combined osmotic dehydration and cryogenic freezing process for minimizing quality changes during freezing with application to fruits and vegetables. Journal of Food Processing and Preservation 2017, $41(1), 1-8$.

[19] Chavan, U.D.; Amarowicz, R. Osmotic dehydration process for preservation of fruits and vegetables. Journal of Food Research 2012, 1 (2), 202-209.

[20] Azuara, E.; Flores, E.; Beristain, C.I. Water diffusion and concentration profiles during osmodehydration and storage of apple tissue. Food and Bioprocess Technoogy 2009, 2 (4), 361-367.

[21] Sun, D-W. Emerging Technologies for Food Processing; Academia Press; United States of America, 2014.

[22] Wray, D.; Ramaswamy, H.S. Development of a microwave - vacuum- based dehydration technique for fresh and microwave - osmotic (MWODS) pretreated whole cranberries (Vaccinium macrocarpon). Drying Technology 2015, 33, 796-807.

[23] Wray, D.; Ramaswamy, H.S. Microwave-osmotic dehydration of cranberries under continuous flow medium spray conditions. International Journal of Microwave Science and Technology, 2013, 2013, 1-11.

[24] Azarpazhooh, E.; Ramaswamy, H.S. Microwave-osmotic dehydration of apples under continuous flow medium spray conditions : comparison with other methods. Drying Technology, 2010, 28, 49-56.

[25] Azarpazhooh, E.; Ramaswamy, H.S. Evaluation of diffusion and azuara models for 
mass transfer kinetics during microwave-osmotic dehydration of apples under continuous flow medium-spray conditions. Drying Technology, 2010, 28, 57-67.

[26] AOAC. Official Method of Analysis of AOAC International, 2000.

[27] Li, H.; Ramaswamy, H.S. Osmotic dehydration of apple cylinders: 1. Conventional batch processing conditions. Drying Technology 2006, 24 (5), 619-630.

[28] Azuara, E.; Cortes, R.; Garcia, H.S.; Beristain, C.I. Kinetic model for osmotic dehydration and its relationship with Fick's second law. International Journal of Food Science and Technology, 1992, 27, 409-418.

[29] Assis, F.R.; Morais, R.M.S.C.; Morais, A.M.M.B. Mass transfer in osmotic dehydration of food products: Comparison between mathematical models. Food Engineering Reviews 2016, 8 (2), 116-133.

[30] Barbosa Júnior, J.L.; Cordeiro Mancini, M.; Hubinger, M.D. Mass transfer kinetics and mathematical modelling of the osmotic dehydration of orange-fleshed honeydew melon in corn syrup and sucrose solutions. International Journal of Food Science and Technology 2013, 48 (12), 2463-2473.

[31] Ramya, H.G.; Kumar, S. Evaluation of mass transfer kinetics for osmotic dehydration of oyster mushrooms (Pleurotus sajor-caju) in salt-sugar solution. Proceedings of the National Academy of Sciences, India Section B: Biological Sciences 2015, 85 (2), 517-525.

[32] Mayor, L.; Moreira, R.; Chenlo, F.; Sereno, A.M. Osmotic dehydration kinetics of pumpkin fruits using ternary solutions of sodium chloride and sucrose. Drying Technology 2007, 25, 1749-1758.

[33] El-Aouar, Â.A.; Azoubel, P.M.; Barbosa, J.L.; Xidieh Murr, F.E. Influence of the osmotic agent on the osmotic dehydration of papaya (Carica papaya L.). Journal of Food Engineering 2006, 75 (2), 267-274.

[34] Luchese, C.L.; Gurak, P.D.; Marczak, L.D.F. Osmotic dehydration of physalis 
(Physalis peruviana L.): Evaluation of water loss and sucrose incorporation and the quantification of carotenoids. LWT - Food Science and Technology 2015, 63 (2), 1128-1136.

[35] Pan, Y.K.; Zhao, L.J.; Zhang, Y.; Chen, G.; Mujumdar, A.S. Osmotic Dehydration Pretreatment in Drying of Fruits and Vegetables. Drying Technology 2003, 21 (6), $1101-1114$.

[36] Manafi, M.; Hesari, J.; Peighambardoust, H.; Khoyi, M.R. Osmotic dehydration of apricot using salt-sucrose solutions. International Journal of Biological, Biomolecular, Agricultural, Food and Biotechnology Engineering 2010, 4 (8), 574-577.

[37] Wang, R.; Zhang, M.; Mujumdar, A.S. Effect of Osmotic dehydration on microwave freeze-drying characteristics and quality of potato chips. Drying Technology 2010, 28, 798-806.

[38] Mathlouthi, M. Water content, water activity, water structure and the stability of foodstuffs. Food Control 2001, 12, 409-417.

[39] García, M.; Díaz, R.; Martínez, Y.; Casariego, A. Effects of chitosan coating on mass transfer during osmotic dehydration of papaya. Food Research International 2010, 43, 1656-1660.

[40] Phisut, N. Factors affecting mass transfer during osmotic dehydration of fruits. International Food Research Journal 2012,19 (1), 7-18. 


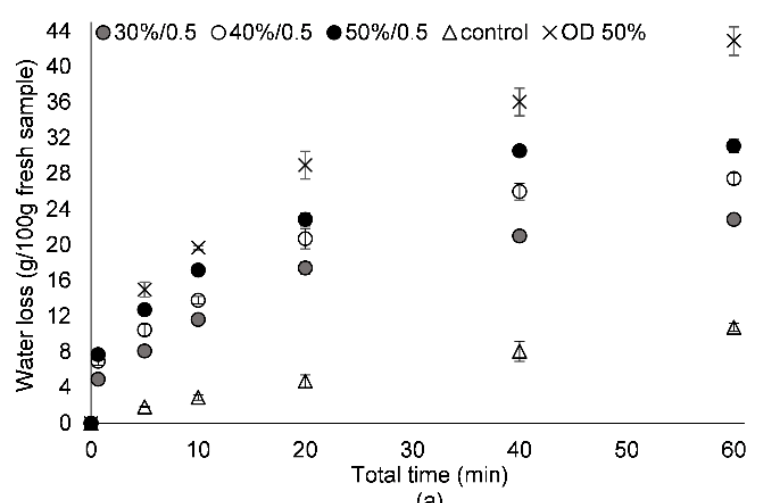

(a)

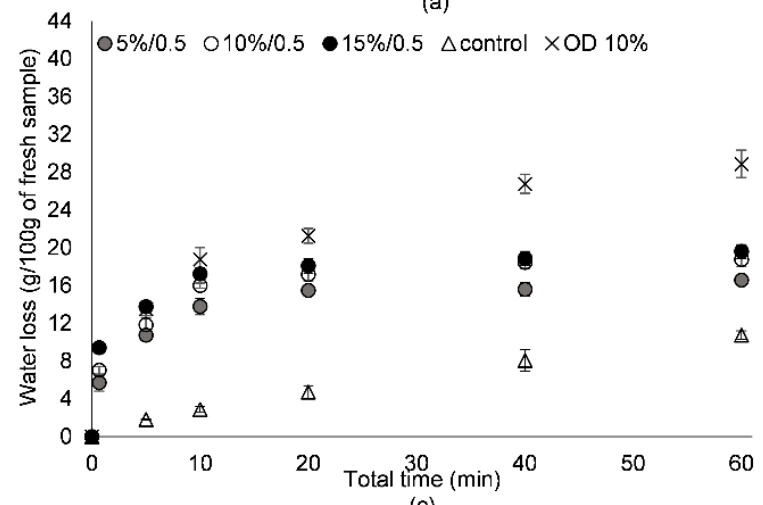

(c)

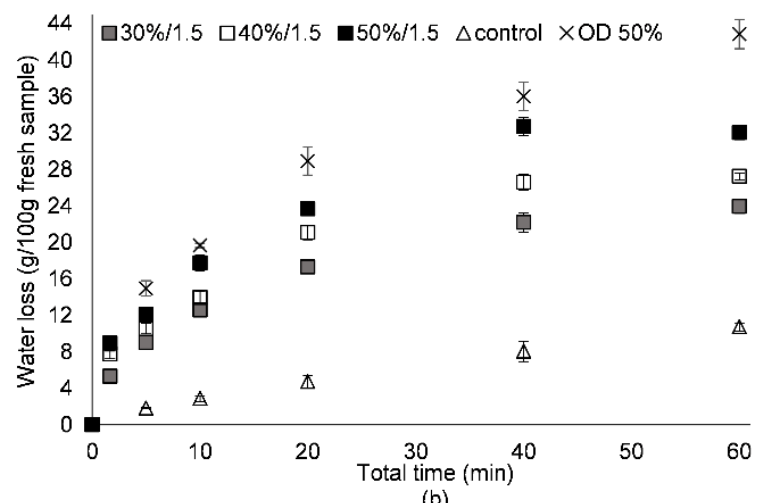

(b)

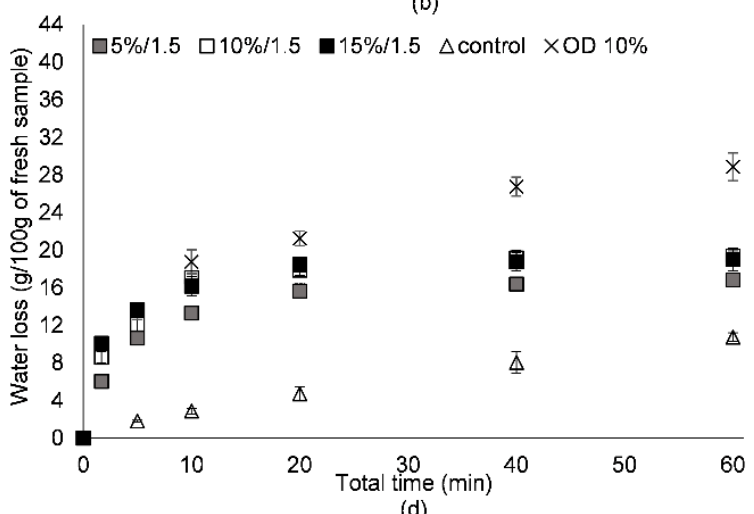

(d)

Figure 1. The variation of water loss as a function of time (a) sucrose; (b) $\mathrm{NaCl}$ solutions for post-dipping and conventional osmotic dehydration treatments, and control samples. The concentration of the solution and dipping time is minutes are shown in figure. $(\mathrm{OD}=$ osmotic dehydration). 


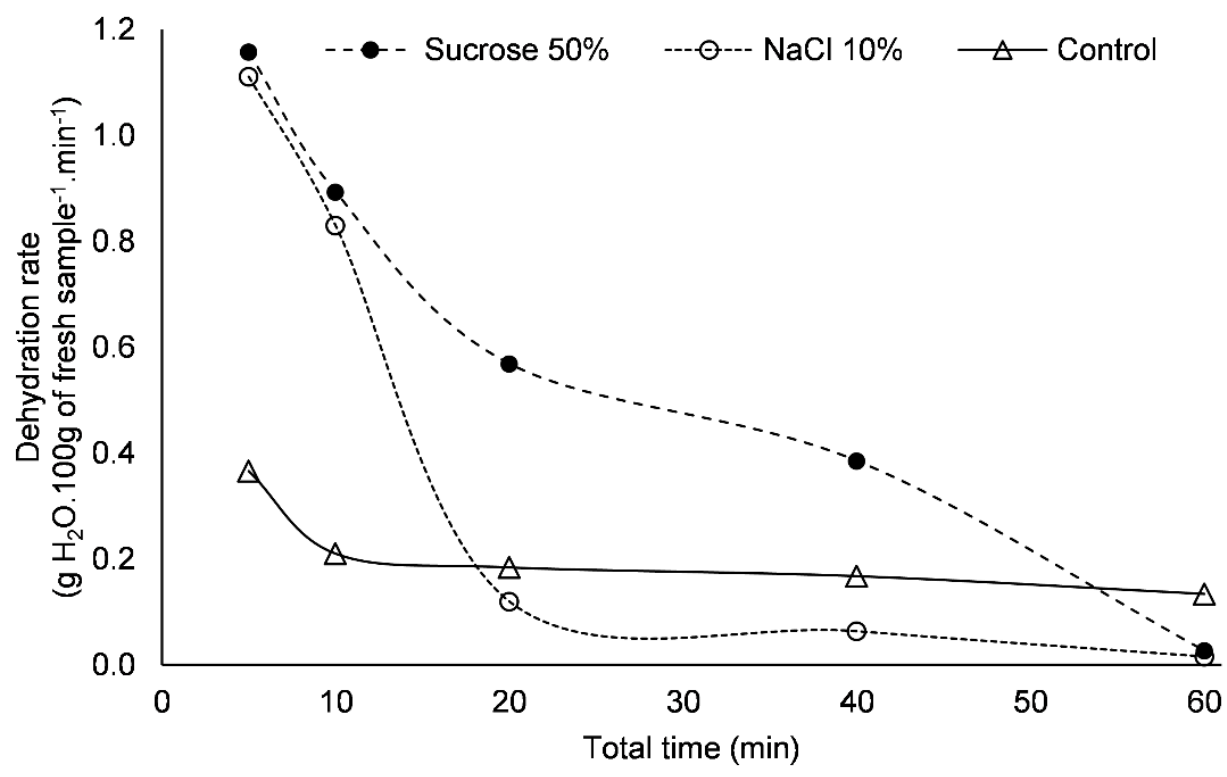

Figure 2. Dehydration rate curve of single stage of post-dipping treatment for sucrose $50 \%$ and $\mathrm{NaCl} 10 \%$, and control samples. 


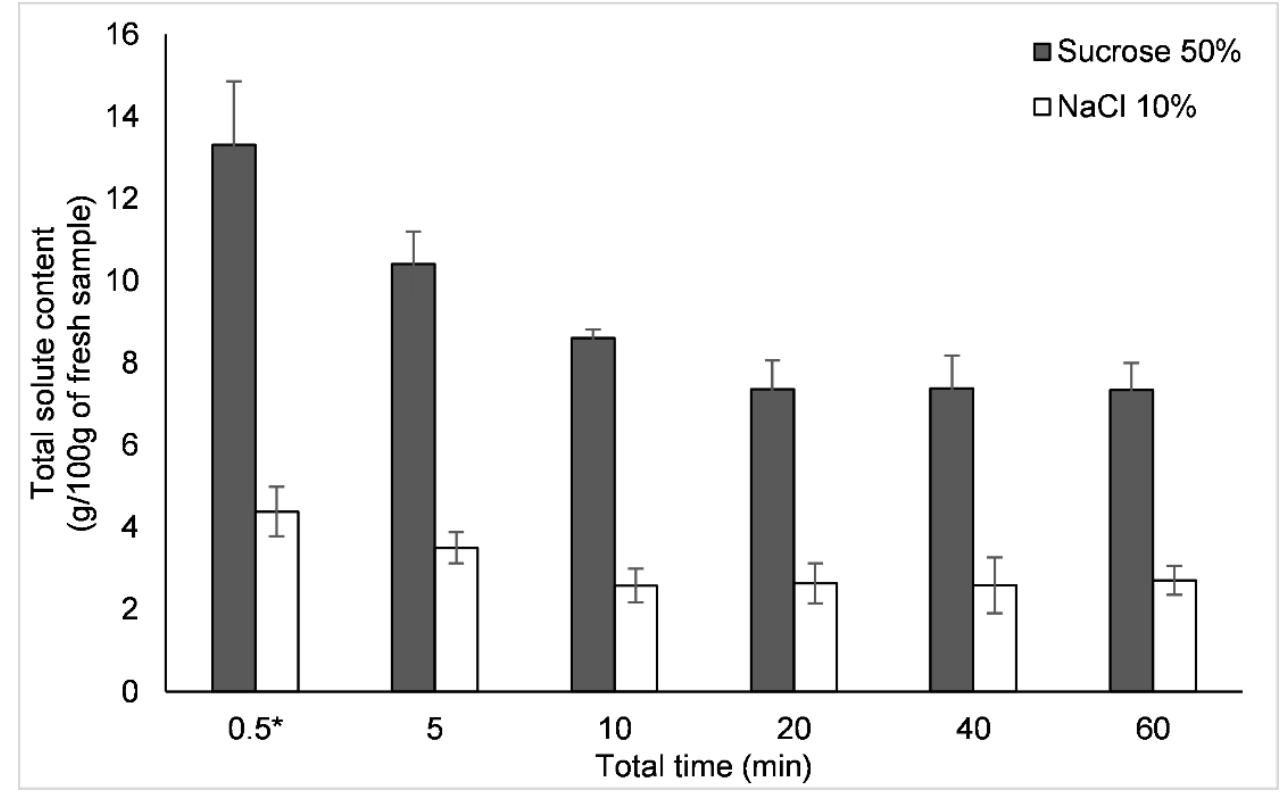

Figure 3. Variation in sucrose and $\mathrm{NaCl}$ content ( $\mathrm{g} / 100 \mathrm{~g}$ fresh sample weight) on the sample with total time. $\left(0.5^{*}\right.$ is the time after sample withdrawn from the osmotic solution and immediately measured the solute content, which is at 0 min of holding time). 


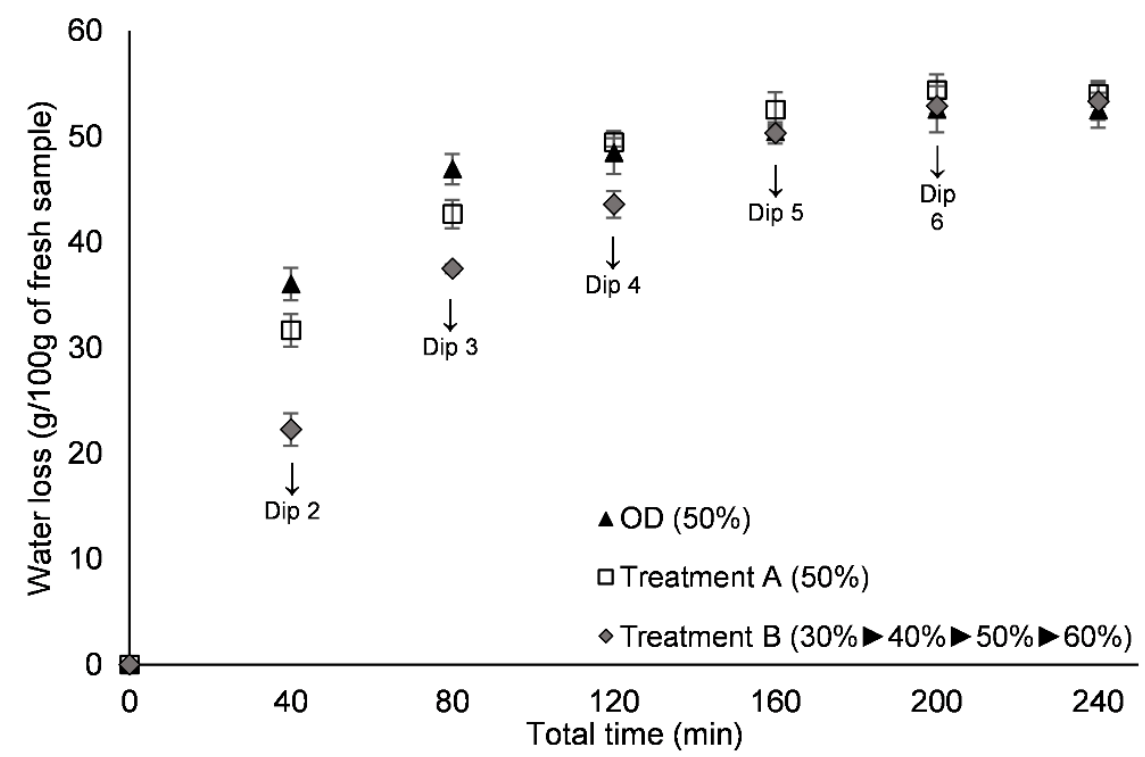

(a)

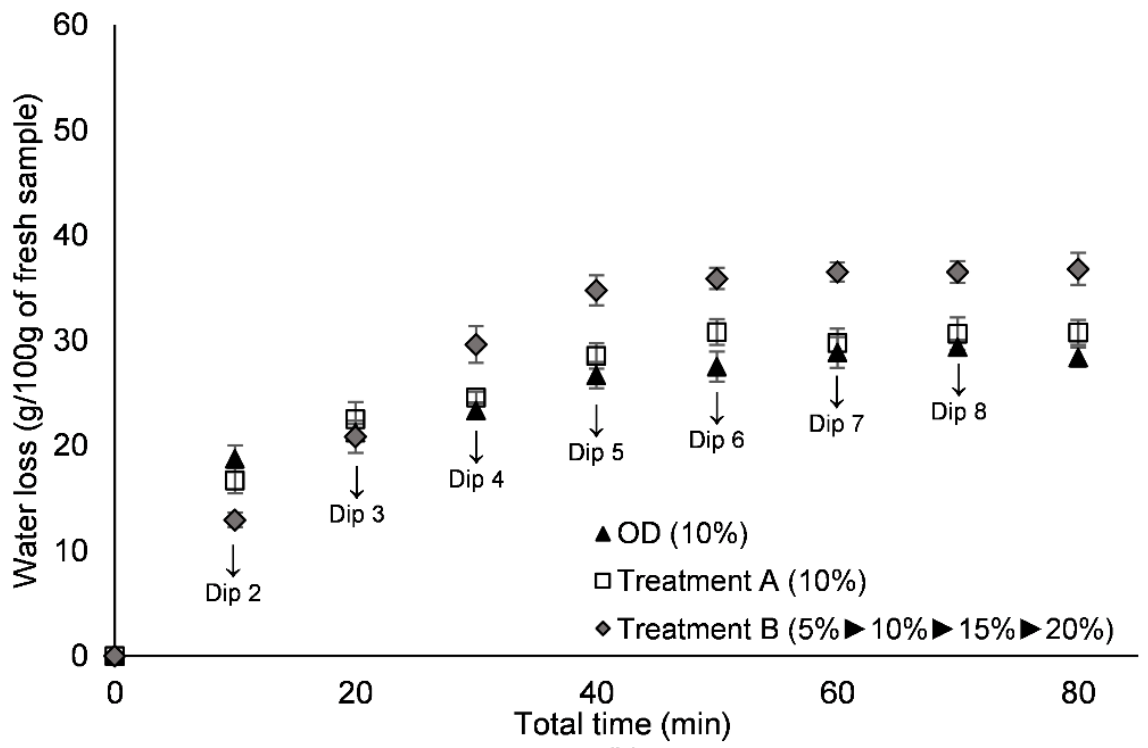

(b)

Figure 4. The variation of water loss as a function of time (a) sucrose; (b) $\mathrm{NaCl}$ solutions for conventional osmotic dehydration, (OD), multi-stage dipping and dehydration in same solution (Treatment A) and multistage dipping and dehydration in progressively solution (Treatment B). The concentrations of the dip solution employed are stated in the figure. $(\downarrow$ shows the time which the re-dipping occurred. In treatment A, samples were re-dipped in same solution as shown in figure, while in treatment B, samples were re-dipped in progressive concentrated solutions based on Table 1). 
Table 1. List of the osmotic solution concentrations and total time employed in treatment B. All dipping time was employed at 0.5 min.

\begin{tabular}{|c|c|c|c|}
\hline \multicolumn{2}{|c|}{ Sucrose case } & \multicolumn{2}{|c|}{$\mathrm{NaCl}$ case } \\
\hline Total time (min) & Osmotic solution (w/v) & Total time (min) & Osmotic solution $(\mathrm{w} / \mathrm{v})$ \\
\hline 0 (Dip 1) & Sucrose $30 \%$ & 0 (Dip 1) & $\mathrm{NaCl} 5 \%$ \\
\hline 40 (Dip 2) & Sucrose $40 \%$ & 10 (Dip 2) & $\mathrm{NaCl} 10 \%$ \\
\hline 80 (Dip 3) & Sucrose $50 \%$ & 20 (Dip 3) & $\mathrm{NaCl} 15 \%$ \\
\hline 120 (Dip 4) & Sucrose $60 \%$ & 30 (Dip 4) & $\mathrm{NaCl} 20 \%$ \\
\hline 160 (Dip 5) & Sucrose $60 \%$ & 40 (Dip 5) & $\mathrm{NaCl} 20 \%$ \\
\hline 200 (Dip 6) & Sucrose $60 \%$ & 50 (Dip 6) & $\mathrm{NaCl} 20 \%$ \\
\hline & & 60 (Dip 7) & $\mathrm{NaCl} 20 \%$ \\
\hline & & 70 (Dip 8) & $\mathrm{NaCl} 20 \%$ \\
\hline
\end{tabular}


Table 2. Kinetic models used in modelling

\begin{tabular}{|c|c|c|c|}
\hline Model & Equation & Equation no. & Reference \\
\hline Azuara & $W L_{t}=\frac{s_{1} t\left(W L_{\infty}\right)}{1+s_{1} t}$ & $(5)$ & {$[20]$} \\
\hline Page & $W L_{t}=\exp \left(-A t^{B}\right)$ & $(6)$ & {$[19]$} \\
\hline Peleg & $W L_{t}=\frac{t}{k_{1}+k_{2} t}$ & $(7)$ & \\
\hline
\end{tabular}

$W L_{t}=$ water loss at any time, $t, W L_{\infty}=$ equilibrium water loss, $s_{1}=$ Azuara's constant, $A$ and $B$ $=$ Page's constants, $k_{1}$ and $k_{2}=$ Peleg's constants.

Table 3. Moisture content (in $\%$ dry basis) and water activity, $a_{\mathrm{w}}$ of potatoes after withdrawn from dip solution at 0.5 min of dipping time, potatoes for conventional osmotic dehydration and control samples 


\begin{tabular}{|c|c|c|c|c|c|}
\hline \multicolumn{6}{|c|}{ Moisture content (\% dry basis) } \\
\hline \multirow{2}{*}{$\begin{array}{c}\text { Total time } \\
\text { (min) }\end{array}$} & \multicolumn{2}{|c|}{ Post-dipping dehydration } & \multicolumn{2}{|c|}{ Osmotic dehydration } & \multirow[t]{2}{*}{ Control } \\
\hline & Sucrose $50 \%$ & $\mathrm{NaCl} 10 \%$ & Sucrose $50 \%$ & $\mathrm{NaCl} 10 \%$ & \\
\hline 5 & $\begin{array}{l}355.37 \pm \\
45.96^{\mathrm{a}, \mathrm{B}}\end{array}$ & $\begin{array}{l}352.40 \pm \\
30.36^{\mathrm{a}, \mathrm{B}}\end{array}$ & $\begin{array}{l}347.38 \pm \\
11.84^{\mathrm{a}, \mathrm{B}}\end{array}$ & $\begin{array}{c}349.37 \pm \\
10.93^{\mathrm{a}, \mathrm{B}}\end{array}$ & $\begin{array}{l}465.11 \pm \\
20.80^{\mathrm{a}, \mathrm{A}}\end{array}$ \\
\hline 10 & $\begin{array}{l}301.37 \pm \\
21.12^{\mathrm{b}, \mathrm{B}}\end{array}$ & $\begin{array}{l}310.67 \pm \\
15.08^{\mathrm{ab}, \mathrm{B}}\end{array}$ & $\begin{array}{c}279.41 \pm \\
5.15^{\mathrm{b}, \mathrm{B}}\end{array}$ & $\begin{array}{l}288.31 \pm \\
14.63^{\mathrm{b}, \mathrm{B}}\end{array}$ & $\begin{array}{l}453.35 \pm \\
24.07^{\mathrm{ab}, \mathrm{A}}\end{array}$ \\
\hline 20 & $\begin{array}{l}265.58 \pm \\
12.54^{b c, C}\end{array}$ & $\begin{array}{c}296.81 \pm \\
19.85^{\mathrm{b}, \mathrm{B}}\end{array}$ & $\begin{array}{c}233.42 \pm \\
8.62^{\mathrm{c}, \mathrm{D}}\end{array}$ & $\begin{array}{l}273.16 \pm \\
13.80^{\mathrm{b}, \mathrm{BC}}\end{array}$ & $\begin{array}{l}443.19 \pm \\
8.05^{\mathrm{ab}, \mathrm{A}}\end{array}$ \\
\hline 40 & $\begin{array}{c}224.70 \pm \\
6.88^{\mathrm{c}, \mathrm{C}}\end{array}$ & $\begin{array}{l}294.64 \pm \\
33.68^{\mathrm{b}, \mathrm{B}}\end{array}$ & $\begin{array}{c}197.73 \pm \\
6.55^{\mathrm{d}, \mathrm{D}}\end{array}$ & $\begin{array}{c}229.67 \pm \\
10.93^{\mathrm{c}, \mathrm{C}}\end{array}$ & $\begin{array}{l}426.84 \pm \\
36.62^{b c, A}\end{array}$ \\
\hline 60 & $\begin{array}{l}225.65 \pm \\
15.10^{c, C}\end{array}$ & $\begin{array}{l}291.46 \pm \\
23.03^{\mathrm{b}, \mathrm{B}}\end{array}$ & $\begin{array}{l}175.73 \pm \\
13.47^{\mathrm{e}, \mathrm{D}}\end{array}$ & $\begin{array}{l}224.57 \pm \\
14.03^{\mathrm{c}, \mathrm{C}}\end{array}$ & $\begin{array}{r}392.20 \pm \\
6.54^{\mathrm{c}, \mathrm{A}}\end{array}$ \\
\hline \multicolumn{6}{|c|}{$a_{\mathrm{w}}$} \\
\hline $\begin{array}{l}\text { Total time } \\
\text { (min) }\end{array}$ & \multicolumn{2}{|c|}{ Post-dipping dehydration } & \multicolumn{2}{|c|}{ Osmotic dehydration } & Control \\
\hline 5 & $\begin{array}{c}0.988 \pm \\
0.003^{\mathrm{a}, \mathrm{A}}\end{array}$ & $\begin{array}{l}0.987 \pm \\
0.007^{\mathrm{a}, \mathrm{A}}\end{array}$ & $\begin{array}{l}0.988 \pm \\
0.002^{\mathrm{a}, \mathrm{A}}\end{array}$ & $\begin{array}{l}0.986 \pm \\
0.001^{\mathrm{a}, \mathrm{A}}\end{array}$ & $\begin{array}{l}0.991 \pm \\
0.005^{\mathrm{a}, \mathrm{A}}\end{array}$ \\
\hline 10 & $\begin{array}{l}0.986 \pm \\
0.001^{\mathrm{a}, \mathrm{A}}\end{array}$ & $\begin{array}{l}0.984 \pm \\
0.001^{\mathrm{a}, \mathrm{A}}\end{array}$ & $\begin{array}{l}0.981 \pm \\
0.005^{\mathrm{a}, \mathrm{A}}\end{array}$ & $\begin{array}{l}0.982 \pm \\
0.002^{\mathrm{ab}, \mathrm{A}}\end{array}$ & $\begin{array}{l}0.988 \pm \\
0.004^{\mathrm{a}, \mathrm{A}}\end{array}$ \\
\hline 20 & $\begin{array}{c}0.977 \pm \\
0.007^{\mathrm{ab}, \mathrm{A}}\end{array}$ & $\begin{array}{c}0.977 \pm \\
0.007^{\mathrm{ab}, \mathrm{A}}\end{array}$ & $\begin{array}{l}0.967 \pm \\
0.005^{b, B}\end{array}$ & $\begin{array}{c}0.977 \pm \\
0.008^{\mathrm{ab}, \mathrm{A}}\end{array}$ & $\begin{array}{l}0.987 \pm \\
0.005^{\mathrm{a}, \mathrm{A}}\end{array}$ \\
\hline 40 & $\begin{array}{l}0.969 \pm \\
0.008^{b, B}\end{array}$ & $\begin{array}{c}0.977 \pm \\
0.003^{\mathrm{ab}, \mathrm{B}}\end{array}$ & $\begin{array}{c}0.962 \pm \\
0.005^{\mathrm{b}, \mathrm{BC}}\end{array}$ & $\begin{array}{c}0.976 \pm \\
0.012^{\mathrm{ab}, \mathrm{A}}\end{array}$ & $\begin{array}{l}0.987 \pm \\
0.006^{\mathrm{a}, \mathrm{A}}\end{array}$ \\
\hline
\end{tabular}




\begin{tabular}{|c|c|c|c|c|c|}
\hline 60 & $0.968 \pm$ & $0.977 \pm$ & $0.961 \pm$ & $0.969 \pm$ & $0.985 \pm$ \\
& $0.005^{\mathrm{b}, \mathrm{BC}}$ & $0.001^{\mathrm{b}, \mathrm{B}}$ & $0.001^{\mathrm{b}, \mathrm{C}}$ & $0.004^{\mathrm{b}, \mathrm{B}}$ & $0.002^{\mathrm{a}, \mathrm{A}}$ \\
\hline
\end{tabular}

Means within a column for each parameter and treatment between total times marked with the same lowercase letters do not differ significantly at $P<0.05$.

Means within a row for each parameter and times between treatments marked with the same uppercase letters do not differ significantly at $P<0.05$.

Table 4. Fitting of water loss data shown in Fig. 1 to Azuara model: $W L_{t}=\frac{s_{1} t\left(W L_{\infty}\right)}{1+s_{1} t}$, Page model: $W L_{t}=\exp \left(-A t^{B}\right)$ and Peleg model: $W L_{t}=\frac{t}{k_{1}+k_{2} t}$.

\begin{tabular}{|l|l|l|}
\hline Model & Parameter & Osmotic solution \\
\hline
\end{tabular}




\begin{tabular}{|c|c|c|c|c|c|c|c|}
\hline & & Sucrose $30 \%$ & Sucrose $40 \%$ & Sucrose $50 \%$ & $\mathrm{NaCI} 5 \%$ & $\mathrm{NaCI} 10 \%$ & $\mathrm{NaCI} 15 \%$ \\
\hline \multirow[t]{5}{*}{ Page } & $A$ & 3.372 & 3.489 & 3.005 & 2.61 & 2.441 & 2.226 \\
\hline & $B$ & -0.2089 & -0.2531 & -0.2332 & -0.0964 & -0.0981 & -0.0809 \\
\hline & $\mathrm{R}^{2}$ & 0.9835 & 0.9868 & 0.9654 & 0.9706 & 0.9788 & 0.9869 \\
\hline & RMSE & 0.0125 & 0.0131 & 0.0241 & 0.01157 & 0.0110 & 0.0089 \\
\hline & $E$ & 0.1166 & 0.1339 & 0.1201 & 0.0851 & 0.0647 & 0.046 \\
\hline \multirow[t]{5}{*}{ Peleg } & $k_{1}$ & 49.4 & 42.73 & 35.65 & 10.54 & 16.39 & 11.84 \\
\hline & $k_{2}$ & 3.406 & 2.806 & 2.541 & 6.132 & 5.056 & 4.921 \\
\hline & $\mathrm{R}^{2}$ & 0.9872 & 0.9836 & 0.9811 & 0.9767 & 0.9819 & 0.9821 \\
\hline & RMSE & 0.0110 & 0.0146 & 0.0178 & 0.0103 & 0.0102 & 0.0103 \\
\hline & $E$ & 0.1379 & 0.1536 & 0.1568 & 0.0684 & 0.1148 & 0.1147 \\
\hline \multirow[t]{5}{*}{ Azuara } & $W_{\infty}(g / g)$ & 0.27 & 0.32 & 0.35 & 0.17 & 0.19 & 0.20 \\
\hline & $s_{1}\left(\min ^{-1}\right)$ & 0.10 & 0.103 & 0.1196 & 0.4783 & 0.4995 & 0.5165 \\
\hline & $\mathrm{R}^{2}$ & 0.9706 & 0.9381 & 0.9594 & 0.9802 & 0.9538 & 0.9187 \\
\hline & RMSE & 0.0141 & 0.0240 & 0.0236 & 0.0080 & 0.0137 & 0.0186 \\
\hline & $E$ & 0.1673 & 0.1784 & 0.1722 & 0.0764 & 0.1177 & 0.1120 \\
\hline
\end{tabular}

Table 5. Solute gain (in $\mathrm{g} / 100 \mathrm{~g}$ of fresh sample) of potatoes after withdrawn from dip solution at 0.5 min of dipping time and potatoes for conventional osmotic dehydration.

\begin{tabular}{|c|c|c|}
\hline \multirow{2}{*}{$(\min )$} & \multicolumn{2}{|c|}{ Sucrose solution } \\
\cline { 2 - 3 } & Single stage dip dehydration & Osmotic dehydration \\
\hline
\end{tabular}




\begin{tabular}{|c|c|c|c|c|}
\hline & $30 \%$ & $40 \%$ & $50 \%$ & $50 \%$ \\
\hline 5 & $1.52 \pm 0.17^{\mathrm{a}, \mathrm{a}}$ & $2.41 \pm 0.24^{\mathrm{a}, \mathrm{b}}$ & $2.53 \pm 0.42^{\mathrm{a}, \mathrm{b}}$ & $3.62 \pm 0.45^{\mathrm{a}, \mathrm{c}}$ \\
\hline 10 & $1.60 \pm 0.30^{\mathrm{ab}, \mathrm{a}}$ & $2.65 \pm 0.20^{\mathrm{a}, \mathrm{b}}$ & $2.73 \pm 0.41^{\mathrm{ab}, \mathrm{b}}$ & $5.59 \pm 0.49^{b, c}$ \\
\hline 20 & $1.89 \pm 0.22^{\mathrm{ab}, \mathrm{a}}$ & $2.77 \pm 0.24^{\mathrm{a}, \mathrm{b}}$ & $3.32 \pm 0.30^{\mathrm{bc}, \mathrm{c}}$ & $6.48 \pm 0.43^{\mathrm{bc}, \mathrm{d}}$ \\
\hline 40 & $1.90 \pm 0.20^{\mathrm{ab}, \mathrm{a}}$ & $2.87 \pm 0.66^{\mathrm{a}, \mathrm{b}}$ & $3.48 \pm 0.35^{\mathrm{c}, \mathrm{b}}$ & $6.67 \pm 0.17^{\mathrm{c}, \mathrm{c}}$ \\
\hline 60 & $1.95 \pm 0.25^{\mathrm{b}, \mathrm{a}}$ & $2.91 \pm 0.55^{\mathrm{a}, \mathrm{b}}$ & $3.52 \pm 0.33^{\mathrm{c}, \mathrm{b}}$ & $7.06 \pm 0.44^{\mathrm{c}, \mathrm{c}}$ \\
\hline \multirow{3}{*}{$\begin{array}{l}\text { Total time } \\
\qquad(\min )\end{array}$} & \multicolumn{4}{|c|}{$\mathrm{NaCl}$ solution } \\
\hline & \multicolumn{3}{|c|}{ Single stage dip dehydration } & Osmotic dehydration \\
\hline & $5 \%$ & $10 \%$ & $15 \%$ & $10 \%$ \\
\hline 5 & $0.74 \pm 0.15^{\mathrm{A}, \mathrm{A}}$ & $1.07 \pm 0.09^{\mathrm{A}, \mathrm{A}}$ & $1.82 \pm 0.34^{\mathrm{A}, \mathrm{B}}$ & $3.06 \pm 0.55^{\mathrm{A}, \mathrm{C}}$ \\
\hline 10 & $0.86 \pm 0.25^{\mathrm{A}, \mathrm{A}}$ & $1.53 \pm 0.38^{\mathrm{AB}, \mathrm{AB}}$ & $1.98 \pm 0.40^{\mathrm{A}, \mathrm{B}}$ & $3.40 \pm 0.85^{\mathrm{A}, \mathrm{C}}$ \\
\hline 20 & $1.01 \pm 0.20^{\mathrm{AB}, \mathrm{A}}$ & $1.92 \pm 0.38^{\mathrm{BC}, \mathrm{B}}$ & $2.27 \pm 0.30^{\mathrm{A}, \mathrm{B}}$ & $4.26 \pm 0.98^{\mathrm{AB}, \mathrm{C}}$ \\
\hline 40 & $1.35 \pm 0.32^{\mathrm{BC}, \mathrm{A}}$ & $2.04 \pm 0.18^{\mathrm{BC}, \mathrm{B}}$ & $3.18 \pm 0.58^{\mathrm{B}, \mathrm{C}}$ & $4.99 \pm 0.55^{\mathrm{B}, \mathrm{D}}$ \\
\hline 60 & $1.54 \pm 0.32^{\mathrm{C}, \mathrm{A}}$ & $2.15 \pm 0.49^{\mathrm{C}, \mathrm{A}}$ & $3.16 \pm 0.69^{\mathrm{B}, \mathrm{B}}$ & $5.00 \pm 0.48^{\mathrm{B}, \mathrm{C}}$ \\
\hline
\end{tabular}

Means within a column for each parameter and treatment between total times marked with the same first letters do not differ significantly at $P<0.05$.

Means within a row for each parameter and times marked between treatments with the same second letters do not differ significantly at $P<0.05$.

Table 6. Process efficiency index (WL/SG) of potatoes under dip dehydration and conventional osmotic dehydration treatments.

\begin{tabular}{|l|l|l|}
\hline Total Time (min) & Single stage dip dehydration & Osmotic dehydration \\
\hline
\end{tabular}




\begin{tabular}{|c|c|c|c|c|}
\hline & Sucrose 50\% & $\mathrm{NaCl} 10 \%$ & Sucrose 50\% & $\mathrm{NaCl} 10 \%$ \\
\hline 5 & $5.13 \pm 0.91^{\mathrm{a}, \mathrm{a}}$ & $11.13 \pm 1.35^{\mathrm{A}, \mathrm{B}}$ & $4.17 \pm 0.35^{\mathrm{ab}, \mathrm{a}}$ & $4.52 \pm 0.86^{\mathrm{A}, \mathrm{A}}$ \\
\hline 10 & $6.42 \pm 1.04^{\mathrm{ab}, \mathrm{b}}$ & $11.05 \pm 2.82^{\mathrm{A}, \mathrm{B}}$ & $3.54 \pm 0.35^{\mathrm{a}, \mathrm{a}}$ & $5.76 \pm 1.33^{\mathrm{A}, \mathrm{A}}$ \\
\hline 20 & $6.92 \pm 0.53^{\mathrm{b}, \mathrm{b}}$ & $9.23 \pm 1.65^{\mathrm{A}, \mathrm{B}}$ & $4.48 \pm 0.28^{\mathrm{b}, \mathrm{a}}$ & $5.15 \pm 0.92^{\mathrm{A}, \mathrm{A}}$ \\
\hline 40 & $8.84 \pm 0.86^{\mathrm{c}, \mathrm{b}}$ & $9.08 \pm 0.55^{\mathrm{A}, \mathrm{B}}$ & $5.40 \pm 0.29^{\mathrm{c}, \mathrm{a}}$ & $5.39 \pm 0.54^{\mathrm{A}, \mathrm{A}}$ \\
\hline 60 & $8.88 \pm 0.72^{\mathrm{c}, \mathrm{b}}$ & $9.11 \pm 1.98^{\mathrm{A}, \mathrm{B}}$ & $6.10 \pm 0.52^{\mathrm{c}, \mathrm{a}}$ & $5.79 \pm 0.34^{\mathrm{A}, \mathrm{A}}$ \\
& & & & \\
\hline & & & & \\
\hline
\end{tabular}

Means within a column for each parameter and treatment between total times marked with the same first letters do not differ significantly at $P<0.05$.

Means within a row for each parameter and total times between treatments marked with the same second letters do not differ significantly at $P<0.05$.

Table 7. Comparison of solute gain (in $\mathrm{g} / 100 \mathrm{~g}$ of fresh sample) and process efficiency index (WL/SG) of potato samples under different treatment conditions: conventional osmotic dehydration (OD), multi-stage dip dehydration in same solution (treatment A) and multi-stage 
dip dehydration in progressively concentrated solution (treatment B). The concentrations of the solutions employed are stated in the table.

\begin{tabular}{|c|c|c|c|c|c|c|}
\hline \multirow{3}{*}{$\begin{array}{l}\text { Time } \\
\text { (min) }\end{array}$} & \multicolumn{6}{|c|}{ Sucrose solution } \\
\hline & \multicolumn{3}{|c|}{ SG (g/100g of fresh sample) } & \multicolumn{3}{|c|}{ WL/SG } \\
\hline & $\begin{array}{c}\text { OD } \\
(50 \%)\end{array}$ & $\begin{array}{c}\text { Treatment A } \\
(50 \%)\end{array}$ & $\begin{array}{c}\text { Treatment B } \\
(30 \%-40 \%-50 \\
\% 60 \%)\end{array}$ & $\begin{array}{c}\text { OD } \\
(50 \%)\end{array}$ & $\begin{array}{l}\text { Treatment A } \\
\qquad(50 \%)\end{array}$ & $\begin{array}{c}\text { Treatment B } \\
\left(\begin{array}{c}30 \%-40 \%-50 \\
\%-60 \%)\end{array}\right.\end{array}$ \\
\hline 40 & $6.67 \pm 0.17^{\mathrm{a}, \mathrm{c}}$ & $3.07 \pm 0.55^{\mathrm{a}, \mathrm{b}}$ & $2.18 \pm 0.07^{\mathrm{a}, \mathrm{a}}$ & $\begin{array}{l}5.40 \pm \\
0.29^{\mathrm{a}, \mathrm{a}}\end{array}$ & $\begin{array}{l}10.58 \pm \\
2.07^{\mathrm{ab}, \mathrm{b}}\end{array}$ & $10.22 \pm 0.82^{b, b}$ \\
\hline 80 & $7.72 \pm 0.67^{\mathrm{a}, \mathrm{b}}$ & $3.29 \pm 0.80^{\mathrm{a}, \mathrm{a}}$ & $2.79 \pm 0.20^{\mathrm{ab}, \mathrm{a}}$ & $\begin{array}{l}6.11 \pm \\
0615^{\mathrm{a}, \mathrm{a}}\end{array}$ & $13.48 \pm 2.89^{\mathrm{a}, \mathrm{b}}$ & $13.65 \pm 0.97^{\mathrm{c}, \mathrm{b}}$ \\
\hline 120 & $8.45 \pm 0.68^{\mathrm{ab}, \mathrm{b}}$ & $\begin{array}{l}4.34 \pm \\
0.47^{\mathrm{ab}, \mathrm{a}}\end{array}$ & $3.84 \pm 0.32^{\mathrm{bc}, \mathrm{a}}$ & $\begin{array}{l}5.77 \pm \\
0.57^{\mathrm{a}, \mathrm{a}}\end{array}$ & $\begin{array}{l}11.49 \pm \\
1.15^{\mathrm{ab}, \mathrm{b}}\end{array}$ & $11.39 \pm 1.01^{\mathrm{bc}, \mathrm{b}}$ \\
\hline 160 & $\begin{array}{l}9.87 \pm \\
1.36^{\mathrm{abc}, \mathrm{b}}\end{array}$ & $\begin{array}{l}5.03 \pm \\
0.59^{\mathrm{bc}, \mathrm{a}}\end{array}$ & $4.84 \pm 0.65^{\mathrm{c}, \mathrm{a}}$ & $\begin{array}{l}5.17 \pm \\
0.60^{\mathrm{a}, \mathrm{a}}\end{array}$ & $\begin{array}{l}10.51 \pm \\
0.91^{\mathrm{ab}, \mathrm{b}}\end{array}$ & $10.58 \pm 1.86^{\mathrm{b}, \mathrm{b}}$ \\
\hline 200 & $\begin{array}{l}11.16 \pm \\
1.97^{\mathrm{bc}, \mathrm{b}}\end{array}$ & $\begin{array}{l}6.10 \pm \\
0.48^{\mathrm{cd}, \mathrm{a}}\end{array}$ & $7.28 \pm 0.86^{\mathrm{d}, \mathrm{a}}$ & $\begin{array}{l}4.84 \pm \\
0.98^{\mathrm{a}, \mathrm{a}}\end{array}$ & $8.96 \pm 0.78^{\mathrm{a}, \mathrm{b}}$ & $7.35 \pm 0.98^{\mathrm{a}, \mathrm{b}}$ \\
\hline 240 & $11.97 \pm 2.34^{\mathrm{c}, \mathrm{b}}$ & $6.73 \pm 0.89^{\mathrm{d}, \mathrm{a}}$ & $7.14 \pm 0.43^{\mathrm{d}, \mathrm{a}}$ & $\begin{array}{l}4.53 \pm \\
0.99^{\mathrm{a}, \mathrm{a}}\end{array}$ & $8.12 \pm 1.00^{\mathrm{a}, \mathrm{b}}$ & $7.49 \pm 0.54^{\mathrm{a}, \mathrm{b}}$ \\
\hline \multirow{2}{*}{$\begin{array}{l}\text { Time } \\
(\min )\end{array}$} & $\mathrm{SG}(\mathrm{g}$ & $/ 100 \mathrm{~g}$ of fresh & $\mathrm{NaCl}$ so & $\mathrm{NaCl}$ solution & WL/SG & \\
\hline & $\begin{array}{c}\text { OD } \\
(10 \%)\end{array}$ & $\begin{array}{c}\text { Treatment A } \\
(10 \%)\end{array}$ & $\begin{array}{c}\text { Treatment B } \\
\left(\begin{array}{c}5 \%-10 \%-15 \\
\%-20 \%)\end{array}\right.\end{array}$ & $\begin{array}{c}\text { OD } \\
(10 \%)\end{array}$ & $\begin{array}{c}\text { Treatment A } \\
(10 \%)\end{array}$ & $\begin{array}{l}\text { Treatment B } \\
\begin{array}{l}(5 \%-10 \%-1 \\
5 \%-20 \%)\end{array}\end{array}$ \\
\hline
\end{tabular}




\begin{tabular}{|c|c|c|c|c|c|c|}
\hline 10 & $3.40 \pm 0.85^{\mathrm{A}, \mathrm{B}}$ & $\begin{array}{c}1.41 \pm \\
0.18^{\mathrm{A}, \mathrm{A}}\end{array}$ & $1.10 \pm 0.35^{\mathrm{A}, \mathrm{A}}$ & $\begin{array}{l}5.76 \pm \\
1.33^{\mathrm{A}, \mathrm{A}}\end{array}$ & $\begin{array}{l}11.96 \pm \\
1.13^{\mathrm{AB}, \mathrm{B}}\end{array}$ & $\begin{array}{l}12.72 \pm \\
3.94^{\mathrm{AB}, \mathrm{B}}\end{array}$ \\
\hline 20 & $\begin{array}{c}4.26 \pm \\
0.98^{\mathrm{AB}, \mathrm{B}}\end{array}$ & $\begin{array}{c}2.14 \pm \\
0.75^{\mathrm{A}, \mathrm{A}}\end{array}$ & $1.61 \pm 0.44^{\mathrm{AB}, \mathrm{A}}$ & $\begin{array}{l}5.15 \pm \\
0.92^{\mathrm{A}, \mathrm{A}}\end{array}$ & $\begin{array}{l}11.33 \pm \\
3.31^{\mathrm{AB}, \mathrm{B}}\end{array}$ & $13.90 \pm 4.94^{\mathrm{B}, \mathrm{B}}$ \\
\hline 30 & $\begin{array}{c}4.56 \pm \\
0.74^{\mathrm{ABC}, \mathrm{B}}\end{array}$ & $\begin{array}{c}1.75 \pm \\
0.35^{\mathrm{A}, \mathrm{A}}\end{array}$ & $2.36 \pm 0.33^{\mathrm{BC}, \mathrm{A}}$ & $\begin{array}{c}5.20 \pm \\
0.72^{\mathrm{A}, \mathrm{A}}\end{array}$ & $\begin{array}{l}14.50 \pm \\
3.23^{\mathrm{AB}, \mathrm{B}}\end{array}$ & $\begin{array}{l}12.83 \pm \\
2.55^{\mathrm{AB}, \mathrm{B}}\end{array}$ \\
\hline 40 & $\begin{array}{c}4.99 \pm \\
0.55^{\mathrm{BC}, \mathrm{C}}\end{array}$ & $\begin{array}{c}1.93 \pm \\
0.20^{\mathrm{A}, \mathrm{A}}\end{array}$ & $3.21 \pm 0.55^{\mathrm{CD}, \mathrm{B}}$ & $\begin{array}{l}5.39 \pm \\
0.54^{\mathrm{A}, \mathrm{A}}\end{array}$ & $14.93 \pm 1.60^{\mathrm{B}, \mathrm{C}}$ & $\begin{array}{c}11.11 \pm \\
2.25^{\mathrm{AB}, \mathrm{B}}\end{array}$ \\
\hline 50 & $\begin{array}{c}5.17 \pm \\
0.68^{\mathrm{BC}, \mathrm{B}}\end{array}$ & $\begin{array}{c}2.34 \pm \\
0.28^{\mathrm{AB}, \mathrm{A}}\end{array}$ & $4.20 \pm 0.57^{\mathrm{DE}, \mathrm{B}}$ & $\begin{array}{c}5.37 \pm \\
0.51^{\mathrm{A}, \mathrm{A}}\end{array}$ & $\begin{array}{l}13.28 \pm \\
1.01^{\mathrm{AB}, \mathrm{C}}\end{array}$ & $8.66 \pm 1.10^{\mathrm{AB}, \mathrm{B}}$ \\
\hline 60 & $\begin{array}{c}5.00 \pm \\
0.48^{\mathrm{BC}, \mathrm{B}}\end{array}$ & $\begin{array}{c}2.45 \pm \\
0.57^{\mathrm{AB}, \mathrm{A}}\end{array}$ & $5.33 \pm 0.20^{\mathrm{E}, \mathrm{B}}$ & $\begin{array}{c}5.79 \pm \\
0.34^{\mathrm{A}, \mathrm{A}}\end{array}$ & $\begin{array}{l}12.73 \pm \\
3.30^{\mathrm{AB}, \mathrm{B}}\end{array}$ & $6.86 \pm 0.23^{\mathrm{A}, \mathrm{A}}$ \\
\hline 70 & $5.89 \pm 0.40^{\mathrm{C}, \mathrm{B}}$ & $\begin{array}{l}3.20 \pm \\
0.33^{\mathrm{B}, \mathrm{A}}\end{array}$ & $5.11 \pm 0.81^{\mathrm{E}, \mathrm{B}}$ & $\begin{array}{c}4.99 \pm \\
0.24^{\mathrm{A}, \mathrm{A}}\end{array}$ & $9.64 \pm 1.00^{\mathrm{A}, \mathrm{C}}$ & $7.26 \pm 1.01^{\mathrm{A}, \mathrm{B}}$ \\
\hline 80 & $6.05 \pm 0.54^{\mathrm{C}, \mathrm{B}}$ & $\begin{array}{l}3.32 \pm \\
0.56^{\mathrm{B}, \mathrm{A}}\end{array}$ & $5.24 \pm 0.34^{\mathrm{E}, \mathrm{B}}$ & $\begin{array}{l}4.73 \pm \\
0.49^{\mathrm{A}, \mathrm{A}}\end{array}$ & $9.43 \pm 1.29^{\mathrm{A}, \mathrm{C}}$ & $7.04 \pm 0.55^{\mathrm{A}, \mathrm{B}}$ \\
\hline
\end{tabular}

Means within a column for each parameter and treatment between times marked with the same first letters do not differ significantly at $P<0.05$.

Means within a row for each parameter and times between treatments marked with the same second letters do not differ significantly at $P<0.05$. 